This article is presented in English with abstracts in Spanish and Portuguese

Brazilian Journal of Applied Technology for Agricultural Science, Guarapuava-PR, v.6, n.3, p.53-59, 2013

\title{
Cientific Paper
}

\section{Abstract}

The management of spatial arrangement in the maize crop by alteration in the spacing between rows and sowing density has been appointed as one of the most important agronomic practices to maximize the grains yield. The objective of this study was to evaluate the behavior of maize in relation to the reduction of row spacing and the different sowing densities during the off season in the Cerrado region. The experimental design was randomized blocks in factorial scheme $2 \times 5$ with four replications. The treatments consisted of two spacing between rows $(0.45 \mathrm{~m}$ and $0.90 \mathrm{~m})$ and five sowing densities $\left(40,000,55,000,70,000,85,000\right.$ and 100,000 plants ha $\left.{ }^{-1}\right)$. It was not found significan response for the reduction of row spacing for the assessed characteristics in maize crop. The increase of sowing density resulted in plant height, number of grains per row and number of grains per ears reduction in the maize crop; however, there was an increase in yield until the density of 100,000 plants ha-1.

Keywords: Zea mays; spatial arrangement; population of plants; productivity.

\section{Resposta do milho à variação da densidade de semeadura e redução do espaçamento entre linhas no Cerrado}

\section{Resumo}

O manejo do arranjo espacial na cultura do milho pela alteração no espaçamento entre linhas e na densidade de semeadura na linha tem sido apontado como uma das práticas agronômicas mais importantes para maximizar a produtividade de grãos. O objetivo deste trabalho foi avaliar o comportamento do milho à redução de espaçamentos entre linhas e a diferentes densidades de semeadura no período da safrinha ( $\left(2^{\mathrm{a}}\right.$ safra) na região do Cerrado. O delineamento experimental foi em blocos casualizados no esquema fatorial $2 \times 5$ com quatro repetições. Os tratamentos foram compostos por dois espaçamentos entre linhas $\left(0,45 \mathrm{~m}\right.$ e 0,90 m) e cinco densidades de semeadura (40.000, 55.000, 70.000, 85.000 e 100.000 plantas ha-1 $^{-1}$. Não verificouse resposta significativa para a redução do espaçamento entre linhas para as características avaliadas na cultura do milho. $\mathrm{O}$ aumento da densidade de semeadura acarretou à cultura do milho redução na altura de planta, no número de grãos por fileira e no número de grãos por espiga, entretanto, houve incremento na produtividade até a densidade de 100.000 plantas ha $^{-1}$.

Palavras-chave: Zea mays; arranjo espacial; população de plantas; produtividade.

\section{Respuesta del maíz a la variación de la densidad de siembra y reducción del espaciamiento de hileras en el Cerrado}

\section{Resumen}

El manejo de la disposición espacial en el maíz por cambio en el espaciamiento de hileras y en la densidad de siembra en las hileras ha sido considerado como una de las prácticas agronómicas más importantes para maximizar el rendimiento. El objetivo de este estudio fue evaluar el comportamiento de maíz por la reducción del espaciamiento de hileras y

\footnotetext{
Received at: 20/02/2013

Accepted for publication at: 22/11/2013

1 Master student in Production Systems. Faculdade de Engenharia-Universidade Estadual Paulista, UNESP - Ilha Solteira-SP. E-mai teruounesp@gmail.com

2 Prof. Dr. Faculdade de Engenharia-Universidade Estadual Paulista, UNESP - Ilha Solteira-SP. E-mail: ricardo@agr.feis.unesp.br

3 Doctoral student in Agronomy. Faculdade de Engenharia-Universidade Estadual Paulista, UNESP - Ilha Solteira-SP. E-mail: renato goes5@yahoo.com.br

4 Prof. Dr. Faculdade de Engenharia-Universidade Estadual Paulista, UNESP - Ilha Solteira-SP. E-mail: kuniko@bio.feis.unesp.br

5 Prof. Dr. Faculdade de Engenharia-Universidade Estadual Paulista, UNESP - Ilha Solteira-SP. E-mail: arf@agr.feis.unesp.br
}

Applied Research \& Agrotecnology v6 n3 sept/dec. (2013)

Print-ISSN 1983-6325 (On line) e-ISSN 1984-7548 
Takasu et al. (2013)

diferentes densidades de siembra durante el cultivo tardío (segunda temporada) en la región del bioma de Cerrado. El diseño experimental fue de bloques completos al azar en arreglo factorial $2 \times 5$ con cuatro repeticiones. Los tratamientos consistieron en dos distancias entre hileras $(0,45 \mathrm{~m} \mathrm{0,90} \mathrm{m)} \mathrm{y} \mathrm{cinco} \mathrm{densidades} \mathrm{de} \mathrm{siembra}(40.000,55.000,70.000,85.000$ y 100.000 plantas ha $^{-1}$ ). No se ha verificado una respuesta significativa a la reducción de la distancia entre hileras en los caracteres evaluados en el maíz. El aumento de la densidad de siembra ocasionó al maíz reducción en altura de planta, número de granos por hilera y número de granos por mazorca, sin embargo, hube un aumento de la productividad hasta la densidad de 100.000 plantas ha $^{-1}$.

Palabras clave: Zea mays; disposición espacial; población de planta; productividad.

\section{Introduction}

In the grains production systems of the Cerrado, the maize crop is one of the most representatives. Actually, there is an increasingly search for a vertical integration of the yield to increase the efficiency of the productive system and minimize the opening of new areas in the Cerrado (MARCHÃO and BRASIL, 2007).

According to the last accompaniment of the Brazilian season of grains 2011/12 of the CONAB (2012), during the second season (off season) were cultivated around 7.5 millions of hectare from a total of 15.1 millions of hectare of maize crops, with an average yield around 5,100 $\mathrm{kg} \mathrm{ha}^{-1}$. A low yield can be compared to the great regions that produce the cereal, which produced more than $6,000 \mathrm{~kg} \mathrm{ha}^{-1}$.

The introduction of hybrids with high yield potential, the increment in the use of fertilizers, the development of new herbicides, besides of other factors, has caused a constant search, by the researchers and producers, for practices of management that potentiate the grains yield. The choice of the adequate arrangement of plants is one of the most important practices of management to maximize the maize grains yield (MARCHÃO and BRASIL, 2007).

Basically, the spatial arrangement of plants (how plants are distributed in the area) can be manipulated by the alterations in the sowing density, spacing between rows and distribution of plants in the row, and the most favorable spatial arrangement of plants per area due to approximation of lines stimulates the growth rates of the crop in the cycle beginning, increments the interception of incident light in the canopy and increases the efficiency of its use (ARGENTA et al., 2001).

The reduction of the spacing between rows has as advantages the increment in the distance between the plants in the line, providing a more equidistant arrangement of the individuals in the area under cultivation, which enables a reduction in the competition among the plants for water, light and nutrients (ALVAREZ et al., 2006).

ARGENTA et al. (2001) noted that the effect of spacing reduction between rows on the grains yield depended of the hybrid which was being used and of the plants density. They also verified that the grains yield linearly increased with reduction of spacing from $1.00 \mathrm{~m}$ to $0.40 \mathrm{~m}$ for the hybrid Cargill 901 , with increment of $716 \mathrm{~kg} \mathrm{ha}^{-1}$ for every $20 \mathrm{~cm}$ of spacing reduction.

The management of the population density has the greatest effect in the maize grains yield, since small alterations in the population imply in relatively large modifications in the final yield of the crop (SILVA et al., 2006). However, the ideal number of plants per hectare is variable, once the maize plant alters the grains yield according to the level of intraspecific competition proportionate by different plants density (SILVA et al., 1999). Thus, the identification of the plants arrangement, which results in a lesser intraspecific competition allows better harnessing of the available resources for the grains growth and yield.

MARCHÃO et al. (2006), in a study assessing the effect of plants density in reduced spacing between rows, showed that, under densification, more than $70 \%$ of the attenuation of photosynthetically active radiation occurred in the superior part of the plant, until the ear insertion. Still according to these authors, the densification caused by the increase of plants density in reduced spacing increased the canopy capacity of the maize in better intercepting the available solar radiation in determined area of the soil.

In studies developed in the southern region of Brazil, to determine the optimum plant population in maize hybrids with elevated yield potential were obtained maximum grains yield with populations equal or superior to 80,000 plants ha $^{-1}$ (ALMEIDA et al., 2000). 
Maize response to the variation... Resposta do milho à variação...

Respuesta del maíz a la variación...
The current study has as objective to assess the maize crop response to the reduction of spacing between rows $(0.45 \mathrm{~m}$ and $0.90 \mathrm{~m})$ and the density variation of sowing $(40,000,55,000,70,000,85,000$ and 100,000 plants ha $^{-1}$ ) with the implementation being done in the second season of sowing (off season) in the Cerrado region.

\section{Material and Methods}

The study was developed in the experimental area of the Farm of Instruction, Research and Extension of the Faculty of Engineering - UNESP - Ilha Solteira Campus - SP, located in the Selvíria municipality - MS with geographical coordinates of $51^{\circ} 22^{\prime}$ West and $20^{\circ} 22^{\prime}$ South, and $335 \mathrm{~m}$ of altitude. The area soil is of the type Latossolo Vermelho Distrófico álico ${ }^{1}$, clayey texture (EMBRAPA, 2006) being the local annual average rainfall of $1,370 \mathrm{~mm}$, with temperature and air humidity (annual average) of $23.5^{\circ} \mathrm{C}, 70$ to $80 \%$, respectively. In Figure 1 are found the daily values of relative humidity, rainfall and air average temperature, which were registered during the period of the experiment.

Before the installation of the experiment were collected soil samples at the depth of 0.0 to $0.2 \mathrm{~m}$, and submitted to chemical analysis for purposes of

1 Brazilian soil classification. fertility, which revealed the following values: $\mathrm{pH}$ $\left(\mathrm{CaCl}_{2}\right)=4.8 ; 31.0 \mathrm{mg} \mathrm{dm}^{-3}$ of P; 2.3; 15.0; 7.0; 36.0; 24.3 and $60.3 \mathrm{mmol}_{\mathrm{c}} \mathrm{dm}^{-3}$ of $\mathrm{K}, \mathrm{Ca}, \mathrm{Mg}, \mathrm{H}+\mathrm{Al}, \mathrm{SB}$ and CTC, respectively; $19.0 \mathrm{~g} \mathrm{dm}^{-3}$ of organic matter and saturation per bases $(\mathrm{V} \%)=40.0$.

The maize sowing was done in an area with no tillage system, in July $6^{\text {th }}$ of 2011 , with rattles, being the holes spaced equidistantly, according to the desired density and the used spacing. It was used in the fertilization of sowing $250 \mathrm{~kg} \mathrm{ha}^{-1}$ of the formula 04-30-10. The seeds were treated with $37.5 \mathrm{~g}$ of i.a. of imidacloprid $+112.5 \mathrm{~g}$ of i.a. of thiodicarb per $100 \mathrm{~kg}$. The cover fertilization was done in the stage $V_{5}$ (five expanded leaves) and the used dose was of $120 \mathrm{~kg} \mathrm{ha}^{-1}$ of $\mathrm{N}$ in the form of urea ( $45 \%$ of $\mathrm{N})$ and $80 \mathrm{~kg} \mathrm{ha}^{-1}$ of $\mathrm{K}_{2} \mathrm{O}$ in the form of potassium chloride $\left(60 \%\right.$ of $\left.\mathrm{K}_{2} \mathrm{O}\right)$, followed by irrigation with self-propelled cannon (width of approximately $13 \mathrm{~mm}$ ) to minimize the losses of $\mathrm{N}$ by volatilization of the ammonia. For the weed control in post emergence was used $1000 \mathrm{~g} \mathrm{ha}^{-1}$ of i.a. of atrazine $+105.0 \mathrm{~g} \mathrm{ha}^{-1}$ of i.a. of tembotrione in form of mixture in the stage $V_{6}$ of the crop. It was added to the spray the methylated adjuvant ester of soybean oil (720 $\mathrm{g} \mathrm{ha}^{-1}$ of i.a.). Whenever necessary, was done the irrigation with self-propelled cannon, with a water width of $20 \mathrm{~mm}$.

The treatments were constituted of the combination between two spacings between rows of 0.45 and $0.90 \mathrm{~m}$ and five densities of sowing with $40,000,55,000,70,000,85,000$ and 100,000 plants ha ${ }^{-1}$.

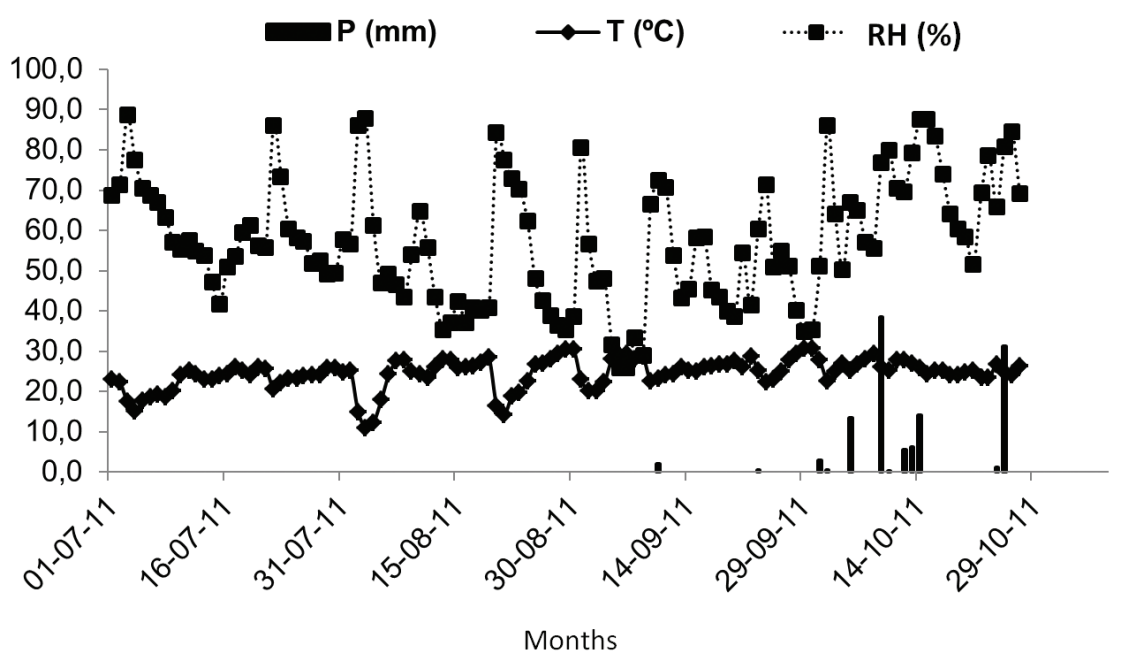

Figure 1. Daily values of relative humidity $(\mathrm{RH})$, rainfall $(\mathrm{P})$ and air average temperature $(\mathrm{T})$, which were registered during the period of the experiment. Selvíria, MS, 2011. 
The used hybrid was the DKB $390 \mathrm{YG}^{\circledR}$, simple hybrid of early cycle with medium-soft grains of yelloworange coloration. The experimental design was of randomized blocks, in factorial scheme $2 \times 5$ (spacing between rows and plants population) with four repetitions per treatment. The plots were constituted by six and four lines of $4.5 \mathrm{~m}$ of length for the spacings of $0.45 \mathrm{~m}$ and $0.90 \mathrm{~m}$ between lines, respectively. For assessment of the agronomic characteristic and of the maize crop yield were used the four and the two central rows in the spacings of 0.45 and 0.90 between lines, respectively.

At the time of full flowering, were measured, in five plants per plot, the following characteristics: plant height (measurement of the stem until the insertion of the leaf "flag") and of the ear (measurement of the stem until the insertion of the first viable ear).

The harvest was done in November $4^{\text {th }}$ of 2011, being assessed: one hundred grains mass (mass corrected to $130 \mathrm{~g} \mathrm{~kg}^{-1}$ of water content in wet basis), number of grains per row, number of grains in the ear and yield. It was used 10 ears randomly in each plot. The yield was obtained from the threshing and weighing of the grains originated from all collected ears in the useful area of the plots, which was converted to $\mathrm{kg} \mathrm{ha}^{-1}$ and corrected to $130 \mathrm{~g} \mathrm{~kg}^{-1}$ of water content (b.u.). The grains water content was obtained by the indirect non destructive electric method, through the use of the portable device Multigrain (Dickey-John ${ }^{\circledR}$ ), which provides direct reading.

For the statistical analysis of the results, it was used the software ESTAT at the levels of 1 and $5 \%$ of probability. When verified significant effect of spacing between lines, it was dose the comparison of measures through the Tukey test and for the significant effect of sowing densities and of significant interaction between sowing densities $x$ spacing between rows was done regression analysis.

\section{Results and Discussions}

In relation to the plants height (Table 1) was not verified significant response for the spacing between rows, however, for the sowing densities was observed decreasing linear adjustment with the increment of density, where the population of 40,000 plants ha-1 presented higher plants height, possibly due to lower intraspecific competition of the hybrid for water, nutrients and solar radiation in the row for smaller populations. Results which are similar to the ones found by DEMÉTRIO et al. (2008), where was also verified that the spacing reduction between rows did not affect the plants height, yet with the increment in the sowing density occurred the increase of plants height. Now ALVAREZ et al. (2006) observed increment in the plants height with the spacing reduction between rows. They also noted higher plants height with the increase of the population density, suggesting a natural tendency of plant height increase in situations of high density.

However, several factors imply for different results in plant height, independent of the spacings and populations of plants that are being used. These differences can be related, particularly to the genotype of the material, which can present characteristics which are independent of the adopted density and spacing.

For the height of insertion of the ear (Table 1) was not observed significant difference, both for the spacing between rows as for the sowing density, however, there was interaction of both treatments (Table 2). Results that agree to those found by STACCIARINI et al. (2010), where testing spacings between rows $(0.45$ and $0.90 \mathrm{~m})$ and plants populations (60,000; 75,000 and 90,000 plants ha-1) also did not find significant responses for the height of insertion of the ear.

Now KAPPES et al. (2011a) verified no significant difference for the reduction of spacing between rows, of 0.90 to $0.45 \mathrm{~m}$, but observed a linear increase of height of insertion of the ear with the increment of plants population, with the density of 90,000 plants per ha-1 presenting plants with higher height of insertion of the ear.

In Table 2 is observed the unfolding of the significant interaction for the height of insertion of the ear, in function of the spacing between rows and sowing density. For the sowing density within the spacing between rows was verified that the one of 40,000 plants ha- ${ }^{-1}$ and the spacing of 0.45 the height of insertion of the ear was smaller in relation to the spacing of $0.90 \mathrm{~m}$. And for the spacing within the density, was observed that the one of $0.45 \mathrm{~m}$ with densities above 55,000 plants ha ${ }^{-1}$ were found plants with higher heights of insertion of the ear.

For the number of grains per row and number of grains per ear (Table 1), there was no significant difference for both characteristics with the spacing reduction between rows, however, for the increment of sowing density was verified significant difference in both assessed characteristics, where the increase of the sowing density resulted in a reduction in the number of grains per row and in the number of 


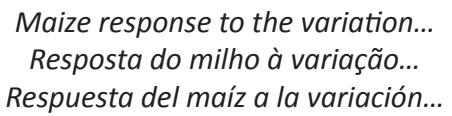

Table 1. Average values of height of the plant (HP), hight of insertion of the ear (HE), number of grains per row (NGPR), number of grains per ear (NGPE), mass of a hundred grains (M100) and yield in function of the sowing density and spacing between rows in the maize crop. Selvíria (MS), Brazil (2011). ${ }^{(1)}$

\begin{tabular}{|c|c|c|c|c|c|c|c|}
\hline \multicolumn{2}{|c|}{ Treatment } & \multirow{2}{*}{$\begin{array}{c}\mathbf{H P}(\mathbf{m}) \\
2.45 \mathrm{a}\end{array}$} & \multirow{2}{*}{$\frac{\mathrm{HE}(\mathrm{m})}{1.06 \mathrm{a}}$} & \multirow{2}{*}{$\begin{array}{l}\text { NGPR } \\
26.98 \mathrm{a}\end{array}$} & \multirow{2}{*}{$\begin{array}{c}\text { NGPE } \\
437.61 \mathrm{a}\end{array}$} & \multirow{2}{*}{$\begin{array}{c}\text { M100 } \\
\text { (g) } \\
32.24 \mathrm{a}\end{array}$} & \multirow{2}{*}{$\begin{array}{c}\begin{array}{c}\text { YIELD } \\
\left.\mathbf{( k g ~ h a}^{-1}\right)\end{array} \\
9,661 \mathrm{a}\end{array}$} \\
\hline Spacing & 0.45 & & & & & & \\
\hline (S) & 0.90 & $2.41 \mathrm{a}$ & $1.07 \mathrm{a}$ & $26.48 \mathrm{a}$ & $426.79 \mathrm{a}$ & $32.05 \mathrm{a}$ & $9,292 \mathrm{a}$ \\
\hline \multirow{5}{*}{$\begin{array}{c}\text { Densities (D) } \\
(\text { plants ha-1) }\end{array}$} & 40.000 & $2.63^{(2)}$ & 1.04 & $28.50^{(3)}$ & $478.53^{(4)}$ & 32.95 & $6,295^{(5)}$ \\
\hline & 55.000 & 2.55 & 1.08 & 27.85 & 461.88 & 32.12 & 8,175 \\
\hline & 70.000 & 2.39 & 1.05 & 27.07 & 432.71 & 31.60 & 9,693 \\
\hline & 85.000 & 2.34 & 1.08 & 25.80 & 407.70 & 32.18 & 11,109 \\
\hline & 100.000 & 2.24 & 1.07 & 24.42 & 380.17 & 31.88 & 12,112 \\
\hline \multirow{3}{*}{ Test F } & $E$ & $1.13^{\mathrm{ns}}$ & $0.97^{\mathrm{ns}}$ & $0.68^{\text {ns }}$ & $1.05^{\mathrm{ns}}$ & $0.03^{\text {ns }}$ & $0.82^{\mathrm{ns}}$ \\
\hline & $\mathrm{D}$ & $20.08^{* *}$ & $2.24^{\mathrm{ns}}$ & $5.81^{* *}$ & $11.45^{* *}$ & $0.21^{\mathrm{ns}}$ & $26.08^{* *}$ \\
\hline & $E \times D$ & $1.32^{\mathrm{ns}}$ & $3.20^{*}$ & $0.77^{\mathrm{ns}}$ & $0.85^{\text {ns }}$ & $0.50^{\mathrm{ns}}$ & $0.85^{\text {ns }}$ \\
\hline \multicolumn{2}{|c|}{ CV (\%) } & 4.09 & 3.14 & 7.16 & 7.69 & 9.61 & 13.54 \\
\hline
\end{tabular}

Table 2. Unfolding of the significant interaction referent to the insertion of the ear in function of the spacing between rows and sowing density in the maize crop. Selvíria (MS), Brazil (2011). ${ }^{(1)}$

\begin{tabular}{cccccc}
\hline Spacing between rows & \multicolumn{5}{c}{ Densities (plants ha ${ }^{-1}$ ) } \\
\cline { 2 - 5 }$(\mathbf{m})$ & $\mathbf{4 0 . 0 0 0}$ & $\mathbf{5 5 . 0 0 0}$ & $\mathbf{7 0 . 0 0 0}$ & $\mathbf{8 5 . 0 0 0}$ & $\mathbf{1 0 0 . 0 0 0}$ \\
\hline $0.45^{(2)}$ & $1.01 \mathrm{Bb}$ & $1.08 \mathrm{Aab}$ & $1.06 \mathrm{Aab}$ & $1.06 \mathrm{Aab}$ & $1.10 \mathrm{Aa}$ \\
0.90 & $1.07 \mathrm{Aa}$ & $1.09 \mathrm{Aa}$ & $1.05 \mathrm{Aa}$ & $1.10 \mathrm{Aa}$ & $\mathrm{a}$ \\
\hline
\end{tabular}

(1) Averages followed by the same uppercase in the columns and lowercase in the rows do not differ by the Tukey test at the level of $5 \%$ of probability. (2) $Y=1.06 \times 10-6+0.98 ; R^{2}=0.57$

grains per ears. These results confirm those found by MARCHÃO et al. (2005) and AMARAL FILHO et al. (2005) who also verified reduction in the number of grains per row with the increase of density. Moreover, according to MARCHÃO et al. (2005), the plants density appear to exert greater influence on the length and, consequently, on the number of grains per row in the ear, in detriment to the other assessed traits and these traits reflect the capacity of filling of all the grains which were differentiated in the first stages of development.

For SANGOI (2001) the use of low sowing densities decreases the efficiency of interception of solar radiation in a certain area, increasing the production of grains per individual, with a reduction of the yield per area.

DEMÉTRIO et al. (2008) did not observed difference for the number of grains per ear with the reduction of spacing from 0.80 to 0.40 and found a reduction of the number of grains per ear as an augmentation in the in the population density occurred, as of 50,000 plants ha ${ }^{-1}$, for all the spacings between rows.

As for the mass of one hundred grains (Table 1), it was not verified significant effect for the reduction of spacings between rows and neither for the increase of the sowing densities. Results that agree with those found by CALONEGO et al. (2011), who testing the reduction of spacing from 0.90 to 0.45 $\mathrm{m}$ and using densities of 45,000, 60,000 and 75,000 plants ha ${ }^{-1}$ also did not find significant response for these factors.

KAPPES et al.(2011a) also did not find significant responses for the mass of one hundred grains with the reduction of spacing between rows of 0.90 to 0.45 , however, observed reduction of grains mass with the increase of the plants density of 50,000 to 90,000 plants $\mathrm{ha}^{-1}$, according to these authors this may have been due the greater competition for water, light and nutrients in the greater populations. 
Takasu et al. (2013)

In relation to yield, it was not observed significant response for the reduction of spacing between rows, although the spacing of $0.45 \mathrm{~m}$ showed a tendency of grains yield increase, and regarding the increment in the sowing density was verified a linear elevation of yield, with the population of 100,000 plants ha ${ }^{-1}$ presenting greater yield. Results which corroborate with the ones found by KAPPES et al. (2011a) who also did not obtain significant response for the reduction of spacing between rows, of 0.90 to 0.45 , and verified increase of yield with the increment of the density until the population of 80,000 plants ha-1.

FLESCH and VIERA (2004) did not detect as well significant difference for reduction of spacing in the grains yield of different maize hybrids, however, verified that this practice appeared to be effective in the control of weeds.

Now DEMÉTRIO et al. (2008), testing maize hybrids verified a yield increment around 1,200 $\mathrm{kg} \mathrm{ha}^{-1}$ with the reduction of the spacing between rows of $0.80 \mathrm{~m}$ to $0.40 \mathrm{~m}$. STACCIARINI et al. (2010) obtained greater yield in the reduction of spacing of $0.90 \mathrm{~m}$ between rows to $0.45 \mathrm{~m}$ and in the increase of sowing densities with the population of 90,000 plants $\mathrm{ha}^{-1}$ producing even more in relation to the 60,000 and 75,000 plants ha ${ }^{-1}$.

EMYGDIO and TEIXEIRA (2008) verified that the maize hybrid BRS 1015 presented responsiveness both for the reduction of spacing between rows as for the densification of the plant, and concluded that the reduction of spacing between rows of $0.80 \mathrm{~m}$ to 0.40 ., until a population of 70 mil plants ha ${ }^{-1}$ promoted a grain yield increment.

\section{Conclusion}

The reduction of spacing between rows did not provide significant responses for the analyzed characteristics in the used maize hybrid, however, it was noted a lesser incidence of weeds in the areas where the reduced spacing was used.

The increase in the sowing density provided reduction in the plants height, in the number of grains per row and in the number of grains per ear, on the other hand provided linear increase in the maize grains yield with the increment of the population, where the density of 100,000 plants ha ${ }^{-1}$ presented greater yield.

\section{Acknowledgments}

To the Coordenação de Aperfeiçoamento de Pessoal de Ensino Superior (CAPES), for the scholarship granted to the first author.

\section{References}

ALMEIDA, M.L.; MEROTTO JÚNIOR, A.; SANGOI, L.; ENDER, M.; GUIDOLIN, A.F. Incremento na densidade de plantas: uma alternativa para aumentar o rendimento de grãos de milho em regiões de curta estação estival de crescimento. Ciência Rural, v.30, p.23-29, 2000.

ALVAREZ, C.G.D.; VON PINHO, R.G.; BORGES, I.D. Avaliação de características agronômicas e de produção de forragem e grãos de milho em diferentes densidades de semeadura e espaçamentos entre linhas. Ciência e Agrotecnologia, v.30, n.3, p.402-408, 2006.

AMARAL FILHO, J.P.R.; FORNASIERI FILHO, E.; FARINELLI, R.; BARBOSA, J.C. Espaçamento, densidade populacional e adubação nitrogenada na cultura do milho. Revista Brasileira de Ciência do Solo, v.29, p.467-473, 2005.

ARGENTA, G.; SILVA, P.R.F.; SANGOI, L. Arranjo de plantas em milho: análise do estado-da-arte. Ciência Rural, v.31, n.6, p.1075-1084, 2001.

ARGENTA, G.; SILVA, P.R.F.; BORTOLINI, C.G.; FORSTHOFER, E.L.; MANJABOSCO, E.A.; BEHEREGARAY NETO, V. Resposta de híbridos simples de milho à redução do espaçamento entre linhas. Pesquisa Agropecuária Brasileira, v.36, n.1, p.71-78, 2001. 
Maize response to the variation...

Resposta do milho à variação...

Respuesta del maíz a la variación...

CALONEGO, J.C.; POLETO, L.C.; DOMINGUES, F.N.; TIRITAN, C.S. Produtividade e crescimento de milho em diferentes arranjos de plantas. Revista Agrarian, Dourados, MS, v.4, n.12, p.84-90, 2011.

CONAB - Companhia Nacional de Abastecimento. Acompanhamento de Safra Brasileira: Grãos. Décimo segundo levantamento, setembro/2012. Brasília, DF: Conab, 2012. 30p.

DEMÉTRIO, C.S.; FORNASIERI FILHO, D.; CAZETTA, J.O.; CAZETTA D.A. Desempenho de híbridos de milho submetidos a diferentes espaçamentos e densidades populacionais. Pesquisa Agropecuária Brasileira, v.43, n.12, p.1691-1697, 2008.

EMBRAPA - Empresa Brasileira de Pesquisa Agropecuária. Centro Nacional de Pesquisa de Solos. Sistema brasileiro de classificação de solos. 2.ed. Brasília, DF: Embrapa-SPI; Rio de Janeiro: Embrapa Solos, 2006. 306p.

EMYGDIO, B.M.; TEIXEIRA, M.C.C. Densidade de plantas e espaçamento entre linhas para o híbrido de milho BRS 1015. Circular Técnica 72, Embrapa Clima Temperado (CPACT), Pelotas, RS. 8p., 2008.

FLESCH, R.D.; VIEIRA, L. C. Espaçamento e densidade de milho com diferentes ciclos no oeste de Santa Catarina. Ciência Rural, v.34, n.01, p.25-31, 2004.

KAPPES, C.; ANDRADE, J.A.C.; ARF, O.; OLIVEIRA, A.C.; ARF, M.V.; FERREIRA, J.P. Desempenho de híbridos de milho em diferentes arranjos espaciais de plantas. Bragantia, v.70, n.2, p.334-343, 2011 .

MARCHÃO, R.L.; BRASIL, E.M. Cultivo do Milho Adensado: alternativa para maximizar o rendimento de grãos. Documentos 189, Embrapa Cerrados, Planaltina, DF. 33 p. nov, 2007.

MARCHÃO, R.L.; BRASIL, E.M.; XIMENES, P.A. Interceptação da radiação fotossinteticamente ativa e rendimento de grãos do milho adensado. Revista Brasileira de Milho e Sorgo, v.5, p.170-181, 2006.

MARCHÃO, R.L.; BRASIL, E.M.; DUARTE, J.B.; GUIMARÃES, C.M.; GOMES, J.A. Densidade de plantas e características agronômicas de híbridos de milho sob espaçamento reduzido entre linhas. Pesquisa Agropecuária Tropical, v.35, n.2, p.93-101, 2005.

SANGOI, L. Understanding plant density effects on maize growth and development: an important issue to maximize grain yield. Ciência Rural, v.31, n.01, p.159-168, 2001.

SILVA, P.R.F.; SANGOI, L.; ARGENTA, G.; STRIEDER, M.L. Arranjo de plantas e sua importância na definição da produtividade em milho. Porto Alegre: Evangraf, 2006. 63p.

SILVA, P.R.F. da; ARGENTA, G.; REZERA, F. Resposta de híbridos de milho irrigado à densidade de plantas em três épocas de semeadura. Pesquisa Agropecuária Brasileira, v.34, n.4, p.585-592, 1999.

STACCIARINI, T.C.V.; CASTRO, P.H.C.; BORGES, M.A.; GUERIN, H.F.; MORAES, P.A.C.;GOTARDO, M. Avaliação de caracteres agronômicos da cultura do milho mediante a redução do espaçamento entre linhas e aumento da densidade populacional. Revista Ceres, v.57, n.4, p.516-519. 2010. 